${ }^{9}$ Nilsson, I M, and Olow, B, Acta Chirurgica Scandinavica, 1962, 123, 247.

${ }^{10}$ Merskey, C, Kleiner, G J, and Johnson, A J, Blood, 1966, 28, 1.

11 Alkjaersig, N, Fletcher, A P, and Sherry, S, fournal of Clinical Investigation, 1959, 38, 1086.

12 Howie, P W, et al, Lancet, 1970, 2, 1329.

${ }^{13}$ Langdell, R D, et al, fournal of Laboratory and Clinical Medicine, 1953, 41, 637.

14 Eichelberger, J W, jun, Laboratory Methods of Blood Coagulation, p 63. New York, Harper and Row, 1965.
15 Born, G V R, and Cross, M J, fournal of Physiology, 1963, 168, 178.

${ }^{16}$ Kakkar, V V, Archives of Surgery, 1972, 104, 152.

17 Geigy, Scientific Tables, 7th edn, p 712. Macclesfield, Geigy Pharmaceuticals, 1970

18 Anderson, J A, Biometrika, 1972, 59, 19.

10 Anderson, J A, et al, Quarterly fournal of Medicine, 1972, 41, 175.

${ }^{20}$ Hume, M, and Chan, Y K, Fournal of the American Medical Association, $1967,200,747$.

${ }^{21}$ Hume, M, Glancy, J J, and Chan, Y K, Archives of Surgery, 1968, 97, 894.

\title{
Virus-like particles in paraspinal muscle in scoliosis
}

\author{
J N WEBB, W J GILLESPIE
}

British Medical fournal, 1976, 2, 912-913

\begin{abstract}
Summary
Biopsy material from the skeletal muscle (paraxials) of 21 patients with scoliosis was examined by light and electron microscopy. Virus-like particles, $17 \mathrm{~nm}$ in diameter with a crystalline structure, were identified in the skeletal muscle fibres of four patients. Associated changes in the sarcoplasm included swelling of mitochondria, presence of lipid droplets, and vesicular structures. Serological studies and culture for virus isolation gave negative results. An excess of lipid (predominantly in type 1 fibres) was noted in the skeletal muscle of several other cases. The significance of these findings is obscure, but the morphology of the paraxial muscles of patients with scoliosis and controls is currently being investigated in greater detail.
\end{abstract}

\section{Introduction}

Idiopathic scoliosis is a crippling and distressing disorder of childhood, most cases occurring in young girls. Pathological studies of the musculoskeletal system have not succeeded in elucidating the cause of the condition. ${ }^{1}$ Scoliosis secondary to neurological disease or myopathic processes is well recognised, ${ }^{2}$ and it is therefore tempting to speculate that an undisclosed disorder affecting muscles of the spine might be responsible for causing the condition. Nevertheless, clinical $^{3}$ and traditional histological methods have failed to show any important abnormalities. Hirano ${ }^{4}$ in an electronmicroscopical study has described degenerative changes in the back muscles of patients with idiopathic scoliosis. It was suggested on the basis of these findings that a myopathic process might be implicated in the aetiology of the condition.

\section{Patients and methods}

Through the kindness of colleagues at the Princess Margaret Rose Orthopaedic Hospital, Edinburgh, we have had the opportunity of

Department of Pathology, Western General Hospital, Edinburgh J N WEBB, MD, FRCPED, consultant pathologist

Department of Orthopaedic Surgery, Princess Margaret Rose Hospital, Edinburgh

W J GILLESPIE, MB, FRCSED, consultant orthopaedic surgeon examining biopsy specimens of skeletal muscle (taken from paraspinal muscles: rotators and multifidus) from 21 patients with scoliosis; 12 had idiopathic disease, seven had congenital scoliosis, and two had neurofibromatosis. At open exposure of the spine for intra-articular fusion, or at revision, blocks of muscle tissue were taken from each side from the deeper parts of the paraspinal muscles at the apex of the curve. Frozen sections were cut for histological and histochemical study, and $1-\mathrm{mm}^{3}$ pieces of tissue were fixed in $2.5 \%$ buffered glutaraldehyde for electron microscopy.

\section{Results}

No definite histological abnormality was observed in the muscle on light microscopy and no appreciable changes were seen in the type 1 and type 2 fibres, as shown by the dihydronicotinamide adenine dinucleotide diaphorase and myosin adenosine triphosphatase (at $\mathrm{pH}$ 9.4) methods. In some cases a slight excess of intracellular lipid was noted, mainly in type 1 fibres. This was confirmed on electron microscopy (fig 1).

A wholly unexpected finding in four patients (see table) was the presence of virus-like particles within the muscle fibres (fig 2). They consisted of uniform electron-dense particles aggregated into a

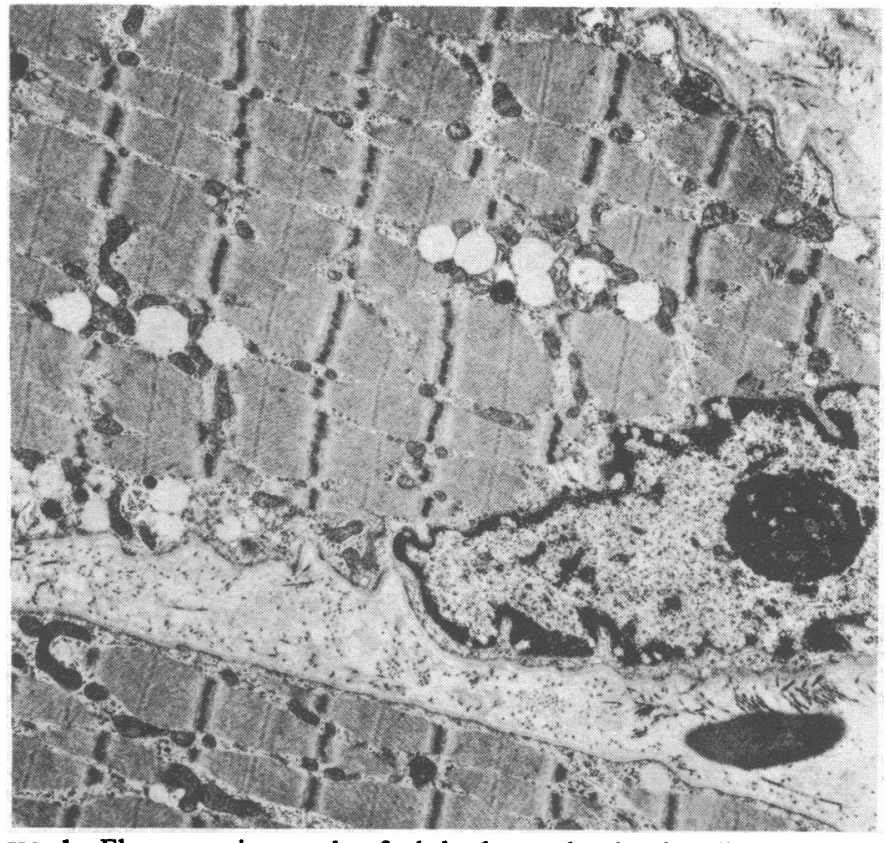

FIG 1-Electron micrograph of skeletal muscle showing lipid droplets between myofibrils and beneath sarcolemmal membrane. ( $x$ 5957.) 
crystalline pattern. The particles measured $17 \mathrm{~nm}$ in diameter and were situated between myofibrils. There were no appreciable degenerative changes in neighbouring myofibrils and there was no cellular reaction. An increase in lipid particles was, however, seen in the vicinity of the particles in one case, and in another the adjacent mitochondria were swollen and seemed degenerate (figs 3 and 4).

Details of four patients in whom virus-like particles were found in muscle fibres

\begin{tabular}{|c|c|c|c|c|}
\hline $\begin{array}{l}\text { Case } \\
\text { No }\end{array}$ & $\underset{\text { (years) }}{\text { Age }}$ & Sex & Type of scoliosis & Operation \\
\hline $\begin{array}{l}1 \\
2 \\
3 \\
4\end{array}$ & $\begin{array}{l}12 \\
13 \\
10 \\
10\end{array}$ & $\begin{array}{l}F \\
F \\
F \\
M\end{array}$ & $\begin{array}{l}\text { Adolescent idiopathic } \\
\text { Adolescent idiopathic } \\
\text { Congenital } \\
\text { Infantile idiopathic }\end{array}$ & $\begin{array}{l}\text { Revision of spinal fusion } \\
\text { Revision of spinal fusion } \\
\text { Spinal fusion } \\
\text { Spinal fusion }\end{array}$ \\
\hline
\end{tabular}

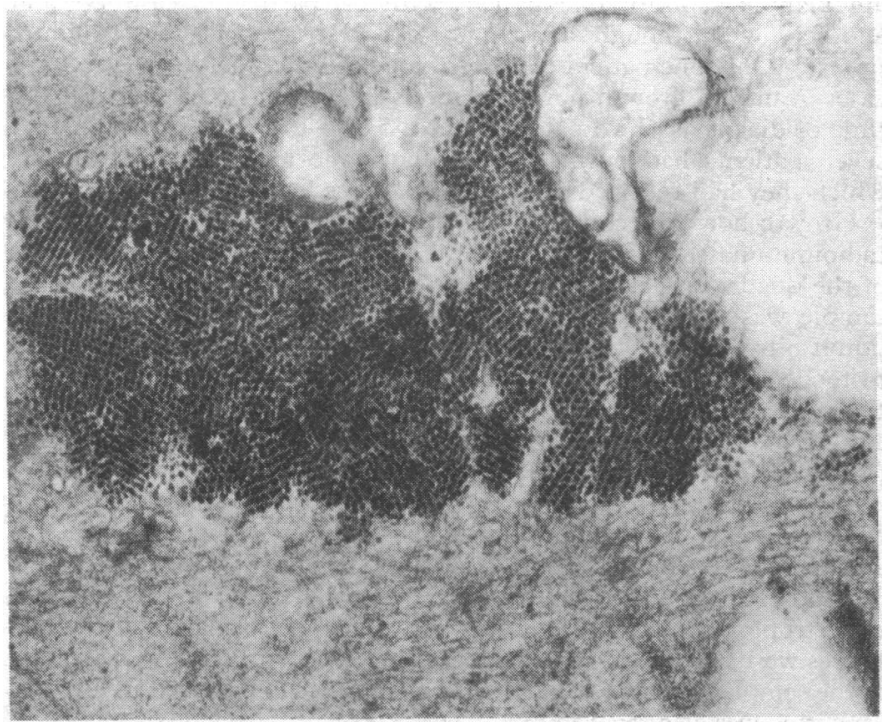

FIG 2-Case 1. Electron micrograph of skeletal muscle showing aggregate of electron-dense virus-like particles with a crystalline structure. $(\times 39067$. $)$

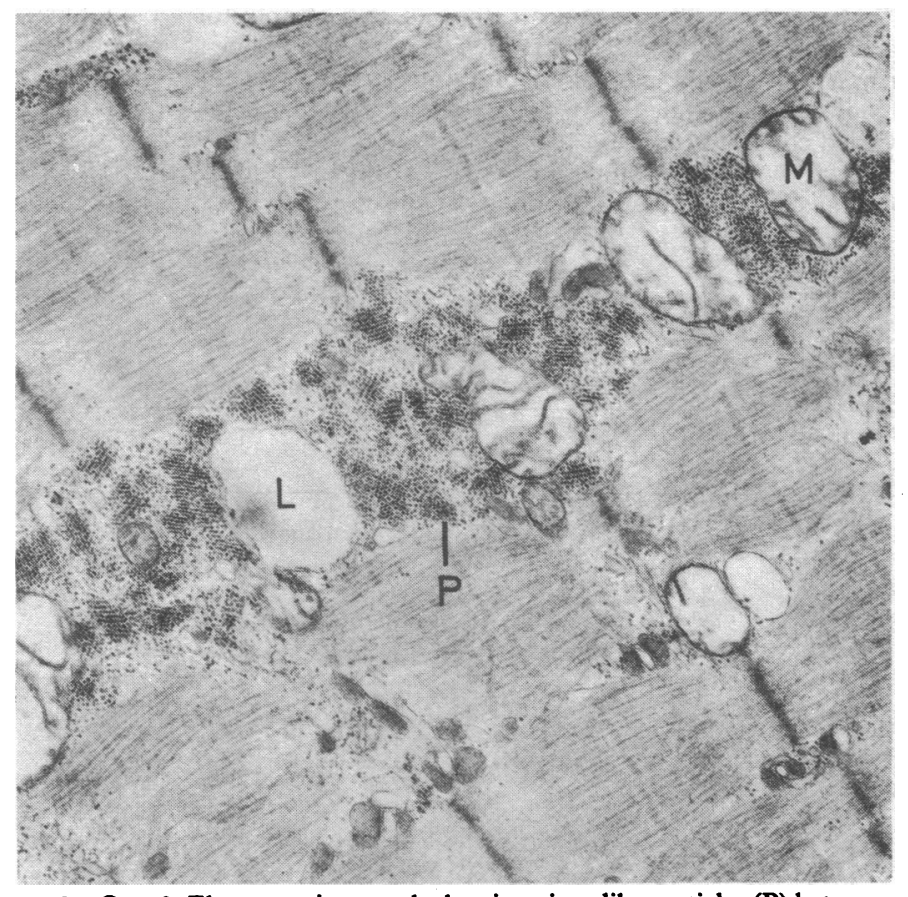

FIG 3-Case 2. Electron micrograph showing virus-like particles $(P)$ between myofibrils. Note swollen mitochondrion (M) and lipid droplets (L). ( $\times 19$ 090.)
These particles were not seen anywhere else and were not observed in any extracellular site. Serological studies in these four patients failed to show raised antibody titres to the following: influenza $A$ and B viruses, Brucella, Leptospira, adenovirus, Chlamydia psittaci, lymphogranuloma venereum virus, Coxiella burneti, respiratory syncytial virus, Mycoplasma pneumoniae, mumps virus, herpes simplex virus, varicella zoster virus, measles virus, and Coxsackie B1-5 viruses. All attempts to isolate virus from biopsy specimens from two of the patients, in cell culture and in suckling mice, failed.

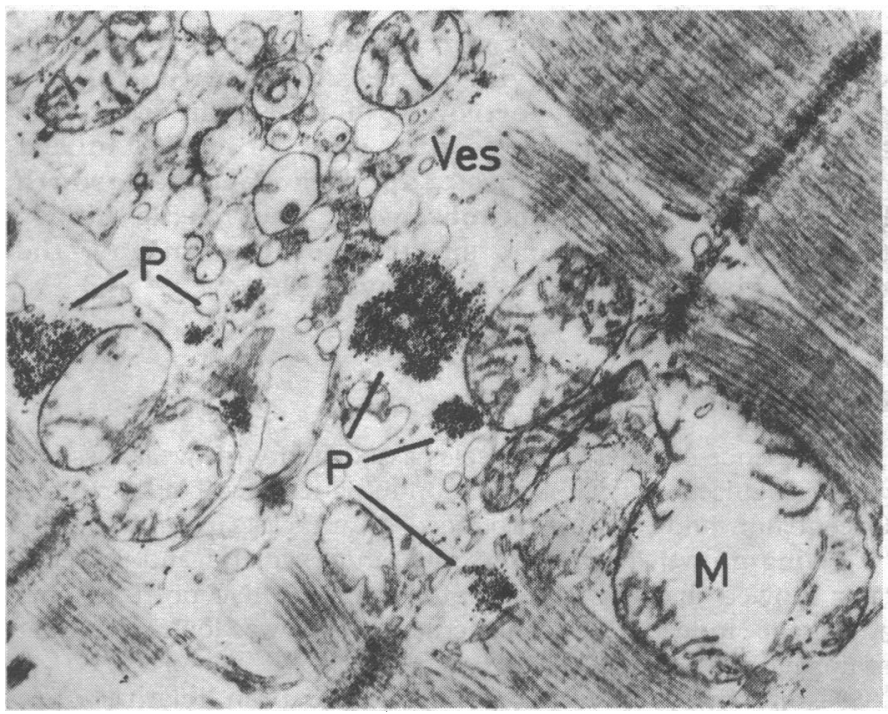

FIG 4-Case 3. Electron micrograph showing many small aggregates of virus-like particles $(P)$ in skeletal muscle, swollen degenerate-looking mitochondria $(M)$, and vesicular bodies (Ves). $(\times 21538$.

\section{Discussion}

The virus-like particles within the skeletal muscle fibres of these patients with idiopathic scoliosis were remarkably similar to virus particles described in a child with a chronic myopathy. ${ }^{5}$ The virus was thought to be a picornavirus, and Coxsackie type A9 virus was isolated from this patient. Identical particles have also been described in the skeletal muscle fibres of a patient with Reye's syndrome. ${ }^{6}$ In an earlier report virus particles were observed in apparently normal eye muscles. ${ }^{7}$ Virus particles of different structure have also been reported in a case of chronic polymyositis. ${ }^{8}$

The implications of our findings are uncertain and our failure to isolate or implicate a virus from any of these four patients is puzzling. We cannot assess the importance of the apparent increase in intracellular lipid in the skeletal muscle in the absence of any comparable control biopsies. We are currently investigating in greater detail the histochemistry and ultrastructure of the paraxial muscles of scoliotic and control patients.

We thank the surgeons at the Princess Margaret Rose Hospital, Edinburgh, for kindly supplying the muscle biopsy specimens. We also thank Dr J F Peutherer, Department of Bacteriology, University of Edinburgh Medical School, for performing the virus studies.

\section{References}

1 British Medical fournal, 1973, 1, 192.

2 British Medical fournal, 1976, 2, 1488.

8 James, J I P, Scoliosis. Edinburgh, Livingstone, 1967.

4 Hirano, S, fournal of the fapanese Orthopaedic Association, 1972, 46, 47.

5 Tang, T T, et al, New England fournal of Medicine, 1975, 292, 608.

- Alvira, M M, and Mendoza, M, New England Medical fournal, 1975, 292, 1297.

7 Caulfield, J B, Robeiz, J J, and Adams, R D, fournal of Pathology and Bacteriology, 1968, 96, 232

${ }^{8}$ Chou, S M, Science, 1967, 158, 1453. 